\title{
Agendas, influences, and capability: Perspectives on practice in design and technology education
}

\author{
Andrew Doyle $^{1}$ (D) Niall Seery ${ }^{1,2}$ (D) Donal Canty $^{3}$ (D) \\ Jeffrey Buckley ${ }^{1}$ (D)
}

Accepted: 10 November 2017/Published online: 16 November 2017

(c) The Author(s) 2017. This article is an open access publication

\begin{abstract}
A philosophical shift in policy now situates the development of technological capability as the focus of Irish technology education. Internationally, the effectiveness of curricular reform in the discipline has previously been called to question, as the legacy of the preceding vocational craft subjects has been seen to throttle the evolution of practice in aligning with emergent policy. As Irish technology education shares this vocational heritage, this research seeks to explore the effectiveness of policy change through an investigation of current practices in the discipline. Specifically, this research seeks to explore the alignment of teachers' perceptions of practice in terms of the focus of learning activities and educational outcomes as prescribed by curricula. A methodological framework was developed to explore teachers' $(n=15)$ perceptions, ecologically rooted in the tasks and activities they use to teach in their classrooms. The results suggest a misalignment between what teachers conceive as important to the discipline, and their enacted practices. The paper unpacks the contentions surrounding this misalignment and discusses factors which appear to influence teachers' perceptions, forming a greater understanding of what influences practice in the discipline.
\end{abstract}

Keywords Technology education - Technological capability Perceptions of practice $\cdot$ Influences on practice

Andrew Doyle

adoyle@kth.se

1 KTH Royal Institute of Technology, Stockholm, Sweden

2 Athlone Institute of Technology, Athlone, Ireland

3 University of Limerick, Limerick, Ireland 


\section{Introduction}

Technology education in Ireland has undergone considerable change in the last number of decades. Reformation of the discipline began in the late 1980's and continues today. The changes to syllabi represent a pragmatic shift from a vocational craft-oriented approach to a design-based philosophy. Since 2007, two curricula have been reformed and implemented (NCCA 2007a, b). With the emergence of new technology education curricula, the National Council for Curriculum and Assessment (NCCA) has sought to redefine the nature of technology education in Ireland. The evolution and implementation of new syllabi to the curriculum encapsulate the potential held by the discipline;

...students grow in competence, grow in confidence, become more enterprising and are empowered in terms of their ability to control elements of the physical environment. These are important educational outcomes, which contribute significantly to the provision of a broad and balanced curriculum and illustrate why participation in technology education represents a valuable educational experience. (NCCA 2007a, b)

These changes suggest that educational goals in technology education have moved beyond the achievement of factual knowledge and skilled performance, and are now more concerned with the development of transferable skills and knowledge. With this paradigm shift, the concept of technological capability has come to the forefront in viewing technology education as part of a broad and balanced curriculum. As the governing body for curriculum and curricular assessment in Ireland, the NCCA have outlined that technological capability is necessary for all aspects of living and working. Although the council acknowledges that many subjects on the curriculum may contribute to the development of technological capability, it is the suite of technology subjects that are viewed as central to its development (NCCA 2004).

\section{Technological capability}

Within the changing nature of technology education, defining the term technological capability has proven to be an unexpectedly complex and difficult task (Gagel 2004), with several conceptions having been put forward over the past decades. In the Irish context, the NCCA (2004) developed a framework that is based upon one's capacity to apply foundational knowledge and skills through thinking and acting creatively and with sensitivity. Skills of communication, design and realisation and problem-solving are viewed as central to the development of capability, as are the abilities to critically evaluate technological activities, artefacts, and systems. Internationally, initial conceptions (Black and Harrison 1985) focused on the capacity to combine designing and making skills, ensuring cognisance is taken for the processes and content required. Gibson (2008) highlights the interactions between problem-solving, value-laden decisions, and relevant skills, all housed within a conceptual knowledge base as fundamental to the espousal of technological capability - defining it as "meaningful practical solutions to real problems framed within an appropriate set of values and underpinned by appropriate knowledge" (p. 11).

In considering the enactment of technological capability, the Assessment and Performance Unit (APU) in England presented a dialectic model of activity in design and technology, emphasising the importance of the process, suggesting that technological capability cannot be developed solely from an underpinning knowledge base (Kelly et al. 
1987), instead resulting from interactions between the mind and hand where ideas are bounced back and forth until suitable solutions are formed (Kimbell et al. 1996). Apparent from all models presented is that technology education is a task-centred activity, and the development of technological capability requires interactions between knowledge, skills, and values (Kimbell 2011). From this, it is evident that to be considered technologically capable it is necessary to apply both knowledge and skills in solving practical problems while acknowledging and engaging with value-laden decisions, also ensuring that the taskcentred nature of technological activity is not lost. The merits of engaging with technology education then come from the development of an expansive variety of abilities required to engage with one's environment, which contribute to a sense of personal empowerment through the development of technological capability.

\section{Practice in technology education}

Internationally, technology, or design and technology education, was traditionally concerned with passing on to students traditional knowledge and skills, where students were required only to learn knowledge, not understand it, and to copy and practice making skills (Owen-Jackson 2015). Accordingly, practices have traditionally relied on the didactic transmission of knowledge, often being compared to the master apprentice model of the medieval guild (Banks 2000), as the teacher was viewed as the subject expert and students as the passive recipients of knowledge (Dakers 2005a). With the emergence of the concept of technological capability, the disciplinary focus of technology education is now characterised by its potential to develop transferable knowledge, skills and attitudes (Dow 2014). Kimbell (2011) suggested that the difficulties in operating within technology education may stem from the nature of knowledge utilised, in that teachers and students reside an intermediate zone of activity, where "hunch, half-knowledge and intuition are essential ingredients" (p. 7).

Studies exploring the effectiveness of policy reform in the discipline have indicated that teachers find it difficult to transition from the traditional model of learning, and that a shift in policy change in terms of curricular outcomes does not necessarily effect practice (Banks and Barlex 1999; Mittell and Penny 1997). Dakers (2005b) suggests that teachers may be reluctant to adopt the new technology education paradigm and that the legacy of behaviourist, teacher-centred, whole class teaching methodologies continues to assert itself as the dominant orthodoxy. In highlighting the importance of moving beyond a commodification of predetermined skills epistemology, Dakers (2005a) states that continuing to value the development of manipulative competencies above broad based attitudinal and cognitive competencies "blurs the edges that serve to distinguish between vocational and technology education” (p. 86).

\section{Study focus}

Concerns have been raised for several decades about the nature of teaching and learning in Irish secondary education (Commission on the Points System 1999; OECD 1991; Shiel et al. 2009). It appears as though the reliance on traditional didactic pedagogies continues to assert itself as the dominant pedagogy. The OECD Teaching and Learning International Study (TALIS) report on Ireland found that Irish teachers are somewhat less supportive of 
constructivist beliefs, and somewhat more supportive of direct transmission beliefs than their counterparts in comparison studies (Shiel et al. 2009). More recently, the prevalence of an exam-oriented approach to teaching and learning in Irish secondary education has been highlighted (Gleeson 2012).

In light of; the philosophical shift in focus of Irish technology education, the legacy issues that have throttled the evolution of practices in technology education internationally (Dakers 2005b; Mittell and Penny 1997), and the calling to question of practices in general Irish education (Gleeson 2014), the research presented herein sets out to explore prevailing practices in the discipline. Specifically, this paper seeks to investigate how teachers describe their practice in the context of Irish technology education. As this research is concerned with enacted practice in technology education, which is ultimately a contextually driven exploration into human behaviour and decision making, the number and nature of emerging variables is likely to become extremely complex. Therefore, it is critical to elicit the perceptions of the people operating within this specific context to ensure a high level of authenticity and validity in potential findings is achieved and to guide the progression of future investigations which occur with a similar agenda in a similar context.

\section{Methodology}

\section{Approach}

To elicit a holistic understanding of teachers' perceptions of practice an interpretive research methodology (Cohen et al. 2007) was employed. Validity of research instruments and findings have traditionally been viewed as the weakness of such an approach, as the potential for capturing decontextualized data arises due to difficulties in controlling variables. To alleviate this potential, a methodological framework converging on the concept of ecological validity was derived through situating the research instrument in teachers' enacted practices. The framework utilises the convergent and discriminant techniques of internal construct validity as depicted by (Cohen et al. 2007). Furthermore, a cross-sectional approach spanning the technology subjects across each year of schooling in lowerand higher-secondary Irish education was decided upon. This approach afforded the opportunity to validate findings convergently (Crano et al. 2015, p. 68), though the analysis of teachers' perceptions in each year of schooling. Previous studies concerning teachers' perceptions of practice range from small case study approaches (Reinsfield and Williams 2017), to larger studies which employ survey instruments and subsequent focus group interviews (Bruce-Davis et al. 2014). The guiding principle used here is that advocated by Glaser and Strauss (1967), in that data were collected until 'theoretical saturation' of the data was deemed to have occurred.

\section{Design of instrument}

A semi-structured interview was chosen as the sole research tool as in keeping with the ecological nature of the framework, it allowed the interviewer to encourage participants to lead conversation, enabling reflection upon past experiences. An interview protocol was derived from the methodological framework, and triangulation of data was achieved through interview questions pertaining to; the focus of learning activities, the intended 
learning outcomes prescribed by teachers, and ultimately, the qualities teachers seek to instil or develop in students.

\section{Participants}

In this study, 15 practicing teachers were interviewed. Participants were selected in order to encompass a diverse variation of geographical and socioeconomic regions in Ireland. The inclusion criterion required participants to be qualified technology teachers, teaching any of the technology education subjects at both lower- and higher-secondary education at the time the study was conducted. All participants were male, ranging in teaching experience from one to 31 years (Mean $=14.1$ and $\mathrm{SD}=9.4$ ), and ranging in age from 26 to 53 years $($ Mean $=37.1$ and $\mathrm{SD}=8.6)$. A detailed description of participant demographic information is provided in Table 1 .

\section{Implementation}

Prior to engaging with the interview, participants were asked to select one learning activity from each of the five compulsory years of schooling to be used as the basis for discussion. Each interview followed the procedures advocated by Cohen et al. (2007). In addition to scripted questions, probing questions were used to further encourage participants to articulate their perceptions of practice. Interviews ranged in duration from 30 to $55 \mathrm{~min}$. Where possible, interviews were conducted on-site $(n=12)$ at the school in which the participant taught, affording participants the opportunity to use physical artefacts or resources relevant to the activities being discussed. In the instances where this was not possible a phone interview $(n=3)$ was undertaken where descriptions of the projects were

Table 1 Participant and school demographic information

\begin{tabular}{|c|c|c|c|c|c|}
\hline \multicolumn{3}{|c|}{ Participant demographic } & \multicolumn{3}{|l|}{ School demographic } \\
\hline No. & Sex & $\begin{array}{l}\text { Experience } \\
\text { (years) }\end{array}$ & School type & Gender & $\sim$ Population \\
\hline PT01 & Male & 4 & Secondary School & All-boys & 600 \\
\hline РT02 & Male & 20 & Secondary School & All-boys & 600 \\
\hline PT03 & Male & 17 & Community College & Mixed & 450 \\
\hline PT04 & Male & 5 & Community College & Mixed & 1200 \\
\hline PT05 & Male & 13 & Community College & Mixed & 1300 \\
\hline РT06 & Male & 27 & Community College & Mixed & 1300 \\
\hline РТ07 & Male & 31 & Secondary School & Mixed & 200 \\
\hline PT08 & Male & 8 & Comprehensive School & Mixed & 650 \\
\hline PT09 & Male & 22 & Community College & Mixed & 1200 \\
\hline PT10 & Male & 24 & Secondary School & Mixed & 250 \\
\hline PT11 & Male & 1 & Community College & Mixed & 900 \\
\hline PT12 & Male & 10 & Secondary School & Mixed & 600 \\
\hline PT13 & Male & 2 & Vocational School & Mixed & 850 \\
\hline PT14 & Male & 10 & Secondary School & All-boys & 450 \\
\hline PT15 & Male & 18 & Vocational School & Mixed & 500 \\
\hline
\end{tabular}


provided by participants. Informed consent was obtained from all participants and assurance was given that the dialogue would remain confidential and identities concealed, ensuring anonymity. Each interview was audio-recorded and transcribed verbatim.

\section{Data analysis}

The analysis of data was undertaken in a number of phases. First, multiple readings of the transcribed interviews systematically informed the development of inclusive, open codes (Patton 2002). This phase focused explicitly on teachers' focus for learning activities. The qualitative data package NVivo facilitated this documentation in a codebook, inclusive of code titles and corresponding definitions. Once saturation of coding was deemed to have been established, coding shifted to a more deductive analysis as the existing codes were applied to the remaining data, while still being open to any potential new inductive codes. The deductive codes were then organised into more inclusive categories. As advocated by Strauss and Corbin (1998), this stage focused on identifying both commonalities and variations between themes. The next stage of analysis explicitly focused on teachers' educational outcomes from each learning activity and were deductively analysed into the cognitive (Anderson and Krathwohl 2001), affective (Krathwohl et al. 1964), and, psychomotor (Dave 1970) domains of learning. This step sought to further validate and expand upon initial findings. Following this, exploratory analytical coding was applied to determine relationships among variables such as teacher professional life phases (Day and Gu 2007), subject, and, year of schooling. Throughout the coding process, the research team documented memos (Cohen et al. 2007, p. 469) to record any thoughts about potential findings. The research team further analysed the memos and analytical codes collaboratively to determine the findings of the data analysis. To ensure the consistency of the interpretation of the data, all categories of findings were reviewed and discussed among the research team until consensus was reached. Finally, an iterative approach was used to explore the findings and ensure that all data were properly coded.

\section{Findings}

Three major themes emerged from the data analysis, (1) the prominence of activities focused on the development of technical competencies, (2) the pressures of meeting the requirements of summative assessment, and, (3) teachers' professional views on capability in the discipline. Table 2 details a breakdown of the findings from the coding process, providing an overview of the generalizability of findings.

\section{Focus of learning activities}

The initial open-coding phase of data analysis identified that teachers' focus for learning activities ranged from the exclusive development of technical competencies to the holistic development of the learner, aligning with the concept of technological capability. To explore the variances and commonalities between learning activities, a five-point continuum was utilised to represent and subsequently quantify teachers' focus of activities (Table 3).

The vast majority of responses referred to the development of content knowledge and craft skills that have traditionally been associated with vocational education (Table 3 ). 
Table 2 Overview of findings

\begin{tabular}{lc}
\hline Theme & Frequency \\
\hline Developing technical competencies & 15 \\
Foundational skills and knowledge base & 12 \\
Outcomes based approach-product centred & 10 \\
Exposure to design—not engagement & 6 \\
Pressures of meeting the requirements of summative assessment & 8 \\
'Stages' of the design process governed by assessment matrix & 5 \\
Truncation of syllabi & \\
Cultural (school) expectations & 2 \\
Professional views on capability & 4 \\
Questioning the nature of syllabus content & \\
Questioning the nature of the assessment system &
\end{tabular}

Table 3 Focus of learning activities

\begin{tabular}{|c|c|c|}
\hline Distribution & Code & Descriptor \\
\hline 34 & $\begin{array}{l}\text { Technical } \\
\text { competency } \\
(-2)\end{array}$ & $\begin{array}{l}\text { Exclusively concerned with the development of content knowledge and } \\
\text { manipulative craft skills }\end{array}$ \\
\hline 16 & $\begin{array}{l}\text { Technical } \\
\text { competency } \\
(-1)\end{array}$ & $\begin{array}{l}\text { Predominantly concerned with the development of content knowledge } \\
\text { and craft skills, but recognition of problem-solving or design }\end{array}$ \\
\hline 2 & Neutral (0) & $\begin{array}{l}\text { The focus of the learning activity is unclear or is concerned with } \\
\text { elements of both technical competency and holistic development }\end{array}$ \\
\hline 13 & $\begin{array}{l}\text { Holistic } \\
\text { development } \\
(+1)\end{array}$ & $\begin{array}{l}\text { Aligned with the concept of technological capability but missing one } \\
\text { critical element (e.g. values or problem-solving) }\end{array}$ \\
\hline 2 & $\begin{array}{l}\text { Holistic } \\
\text { development } \\
(+2)\end{array}$ & $\begin{array}{l}\text { Aligned with the concept of technological capability and concerned } \\
\text { with the development of the student as a whole }\end{array}$ \\
\hline
\end{tabular}

Predominantly skills such as "interpreting working drawings" (PT13), "marking out" (PT05) and "paring" (PT03) or "filing to a line" (PT14) were viewed as the fundamental technical content upon which the subject is based. These skills were viewed as "good practice" (PT02) and it was noted to be fundamental to student's further engagement with the discipline. It was also noted that the development of such competencies was housed within an explicit framework of constraints:

The minimum [student achievement] would have to be their jointing techniques ... it is great that they are able to make nice stuff and bring that home, but that's to maintain their interest. The minimum skills ... they have to be able to do the joints. (PT09) 
The emphasis placed on the exclusive development of technical competencies did not progressively reduce as students progressed through the years of schooling, as was anticipated (Fig. 1). Rather a series of activities focused on the development of knowledge and skills was implemented, a process described as "moving up in the joint stages" (PT05).

The findings from the inductive analysis of learning outcomes support this through the dominance of lower order outcomes evident in each domain of learning (Table 4). With such an emphasis placed on the development of lower order outcomes, the prominence of activities concerned with the product rather than the process of learning became apparent:

Ideally every project should be dealing with problem-solving and the idea of solving the problem is a reward in itself ... that isn't the reality, the reality is that you know, young lads [students] want to have at the end of third year their third-year piece, you know, something that they can bring home, something that they can cherish and so on. I think that that angle seems to work as regards lads [students] completing the project to a good standard. (PT02)

I'd expect that everybody would get it finished to a high standard and working together that's possible, you know. Everybody would bring it home and it would reflect well on what goes on in the school here. (PT07)

To get it finished. To get it finished. Especially at the beginning. I teach in a disadvantaged school and one of our main focuses a lot of the time is getting things finished. Especially with Junior- and Senior-Cycle there's just so many marks going for getting something done and assembled. (PT14)

The emphasis placed on an output driven agenda is perhaps best exemplified through many teachers' reluctance to engage students in authentic design problems. When questioned about this, participants cited students' inability to "conceive" ideas (PT08), or that students lack the "capability design wise" (PT04), despite no prior engagement with design.

10

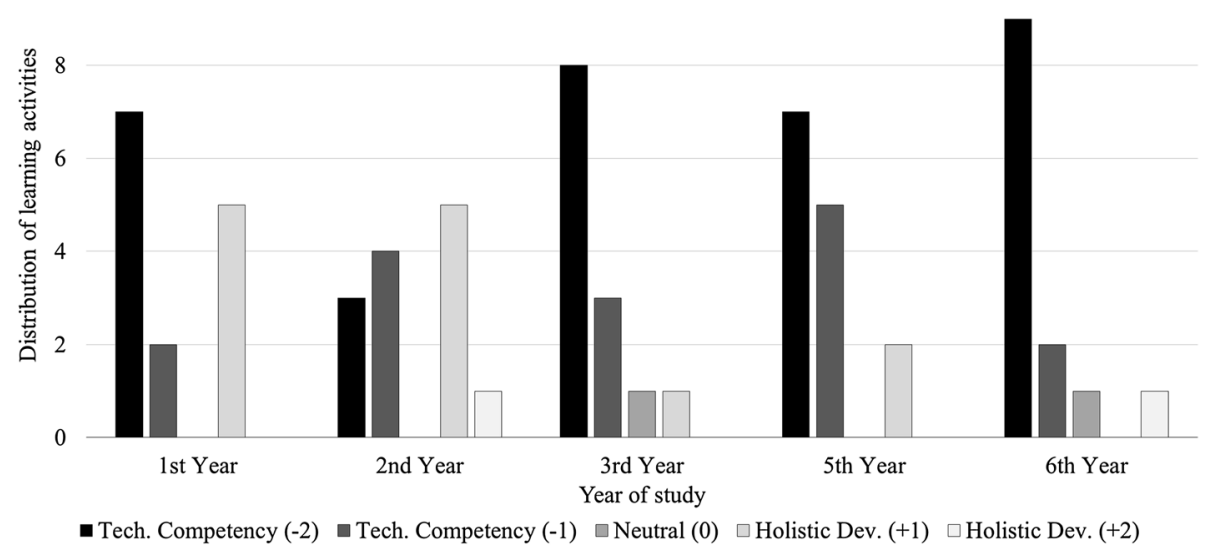

Fig. 1 Distribution of learning activities across year of study 
Table 4 Distribution of educational outcomes

\begin{tabular}{|c|c|c|c|}
\hline Outcome & Distribution & Code & Descriptor \\
\hline \multirow{5}{*}{$\begin{array}{l}\text { Psychomotor (Dave } \\
\text { 1970) }\end{array}$} & 12 & Imitation & Observing and copying someone else \\
\hline & 35 & Manipulation & Guided via instruction to perform a skill \\
\hline & 20 & Precision & $\begin{array}{l}\text { Accuracy, proportion and exactness exist in the skill } \\
\text { performance without the presence of the original } \\
\text { source }\end{array}$ \\
\hline & 0 & Articulation & $\begin{array}{l}\text { Two or more skills combined, sequenced, and } \\
\text { performed consistently }\end{array}$ \\
\hline & 0 & Naturalisation & $\begin{array}{l}\text { Two or more skills combined, sequenced, and } \\
\text { performed consistently and with ease. The } \\
\text { performance is automatic with little physical or } \\
\text { mental exertion }\end{array}$ \\
\hline \multirow{5}{*}{$\begin{array}{l}\text { Affective } \\
\text { (Krathwohl et al. } \\
\text { 1964) }\end{array}$} & 19 & Receiving & Awareness, willingness to hear, selected attention \\
\hline & 35 & Responding & $\begin{array}{l}\text { Active participation on the part of the learners. Attend } \\
\text { and react to a particular phenomenon. Learning } \\
\text { outcomes may emphasize compliance in } \\
\text { responding, willingness to respond, or satisfaction } \\
\text { in responding (motivation) }\end{array}$ \\
\hline & 11 & Valuing & $\begin{array}{l}\text { The worth or value a person attaches to a particular } \\
\text { object, phenomenon, or behaviour. This ranges } \\
\text { from simple acceptance to the more complex state } \\
\text { of commitment. Valuing is based on the } \\
\text { internalization of a set of specified values, while } \\
\text { clues to these values are expressed in the learner's } \\
\text { overt behaviour and are often identifiable }\end{array}$ \\
\hline & 2 & $\begin{array}{l}\text { Organising and } \\
\text { Conceptualising }\end{array}$ & $\begin{array}{l}\text { Organizes values into priorities by contrasting } \\
\text { different values, resolving conflicts between them, } \\
\text { and creating a unique value system. The emphasis } \\
\text { is on comparing, relating, and synthesizing values }\end{array}$ \\
\hline & 0 & $\begin{array}{l}\text { Characterised by } \\
\text { value or value } \\
\text { concept }\end{array}$ & $\begin{array}{l}\text { Has a value system that controls their behaviour? The } \\
\text { behaviour is pervasive, consistent, predictable, and } \\
\text { most important characteristic of the learner. } \\
\text { Instructional objectives are concerned with the } \\
\text { student's general patterns of adjustment (personal, } \\
\text { social, emotional) }\end{array}$ \\
\hline \multirow{6}{*}{$\begin{array}{l}\text { Cognitive } \\
\text { (Anderson and } \\
\text { Krathwohl 2001) }\end{array}$} & 8 & Remembering & Recall or retrieve previous learned information \\
\hline & 30 & Understanding & $\begin{array}{l}\text { Comprehending the meaning, translation, } \\
\text { interpolation, and interpretation of instructions and } \\
\text { problems. State a problem in one's own words }\end{array}$ \\
\hline & 22 & Applying & $\begin{array}{l}\text { Use a concept in a new situation or unprompted use of } \\
\text { an abstraction. Applies what was learned in the } \\
\text { classroom into novel situations in the work place }\end{array}$ \\
\hline & 6 & Analysing & $\begin{array}{l}\text { Separates material or concepts into component parts } \\
\text { so that its organizational structure may be } \\
\text { understood. Distinguishes between facts and } \\
\text { inferences }\end{array}$ \\
\hline & 1 & Evaluating & Make judgments about the value of ideas or materials \\
\hline & 0 & Creating & $\begin{array}{l}\text { Builds a structure or pattern from diverse elements. } \\
\text { Put parts together to form a whole, with emphasis } \\
\text { on creating a new meaning or structure }\end{array}$ \\
\hline
\end{tabular}


Alternatively, the approach that was utilised by the majority of teachers advocated the exposure of student to the problem-solving process, in that there were value-laden decisions to be made but students were not necessarily required to make them:

Then I'd just tease it out with them, like 'what would be key considerations with the locker?'. 'What side of the bed is it going on?'. 'What way will the door be opening if it's at that side of the bed?'. The heights obviously will be important ... (PT02)

Take an ordinary classroom stool. I will get one kid [student] to sit on one and we get him to put his feet up on another and ask him how they feel. They will all complain because their legs are so high. We get out a measuring tape and we will slowly drop down until we get a comfortable height ... There is a little bit of I suppose rationalising to be done, a little bit of work to be done introducing the lesson. They have the option then of either a large single mortise, they have the option of rounding ... some of them put a nice kind of a gradual arc on the piece, they do their own thing ... again we just create a scenario that 'we want this', 'what's our solution' and that's what we come up with. (PT03)

This dialectic between teachers and students occurred typically at the introductory stage of a learning activity.

\section{The pressures of meeting the requirements of summative assessment}

At lower-secondary level the technology subjects are generally assessed at the end of the third year of study which includes a written examination and a design and make assignment, assessed by means of a physical artefact and a design portfolio. In discussing this activity, it emerged that the format of the assessment appeared to significantly contribute to how participants approached the design assignment:

In October, I give them the layout for the brief. I have a template, I've my own template that I use, and I have all the headings because again to be honest with you and I know an awful lot of it ... some might say its spoon-feeding them or whatever but you see when it comes to briefs you have your marking scheme ... you try and cover a brief as best as best as you can. (PT03)

This often resulted in a formulaic approach to designing, in that teachers led students through the "steps" (PT05) of the design process. This atomisation of the design process, to align with the model of the design process which is assessed was further corroborated by participant seven, who actualises an alignment between stages of the design process, and sections of the portfolio-as governed by assessment criteria:

... we look at the [design] booklets of previous years and we look at the sections that have to be done. We will try and go through the design process and we've the five sections to be completed starting off at analysis of design brief. (PT07)

An interesting theme that emerged from the analysis was the relationship between teachers' experience in terms of years of teaching, and their focus for student learning (Fig. 2).

The emphasis among teachers in earlier stages of their careers was situated in students expressing themselves through their work:

I want them all to enjoy the subject and I want them all to get motivated because that is going to feed into everything. First impressions are important. So that's the main 


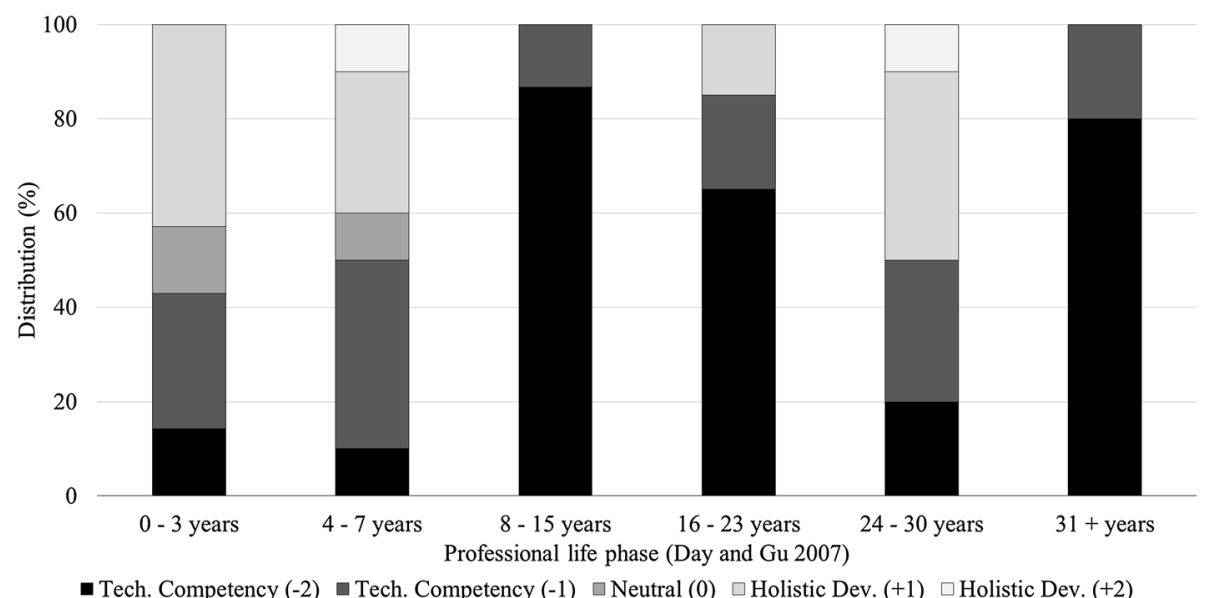

Fig. 2 Distribution of focus of activities across professional life phase

thing I want them all to get from it, we are going to be going through all the other skills again anyway. The main thing I want them to get is I want them to be happy and I want them to be comfortable and I want them to enjoy making it. (PT13)

My role is to let the student come out in the project, let what they have done, and even if they haven't done technology before, they will have experiences in other aspects of their lives that will feed into this so whether it's music or art or whatever so my role is to give them the help that they need to come out in their project. Whatever they are interested in to come out in their own design and try to feed into that because that's going to help them in the long days when they don't feel like doing the project, there's something that's a part of them rather than something separate that they are not into. (PT13)

This theme also permeated into the nature of tasks engaged with and although recognition was taken of the difficulties in engaging with an open-design task, efforts were made to incorporate this medium of learning:

...when it comes to their third-year project they realise, 'what I'm trying to make must fit inside this space'. You're teaching them the concept of solving their own dimensions and finding their own dimensions rather than you telling them what to do. That project takes a long time, there is a lot of creativity required in it, students do a lot of working out... (PT01)

In discussing the focus of learning activities used in higher-secondary education, a very focused narrative pertaining to pressures of meeting the requirements of the assessment system was observed. In the few instances where project-based learning was utilised in the fifth year of schooling, using practical work to support theory was uncovered as a significant theme. Here, model-making activities were used as a support structure to link together different elements of the syllabus. The rationale given for this approach was that past students have found it difficult to conceptualise theoretical aspects of the syllabus and they "need something concrete" (PT01) to aid conceptualisation. This theme was not always pedagogically focused however, as it was established that some teachers' agendas were assessment framework oriented: 
I push the built construction models as much as I can because they overlap with the syllabus ... if that comes up in the exam, which it comes up, it will come up, he's gotten a big head-start in that topic and the other lads [students] will have to study it. (PT04)

I used to do big furniture projects. I stopped doing them four or five years ago because the students weren't getting the result. They were spending too long making pieces of furniture that were too costly. They cost them too much in time and in money and they didn't get the standard that they wanted to get ... but when I changed it from that way the results have improved a lot. (PT09)

Both participants PT04 and PT09 work in the same school. Describing it as "high achieving" (PT04), the expectations placed on both teachers arose in the interviews, indicating the significant influences that school culture may have on practices:

....at the end of the day we are delivering a service. We are expected to make our students excel in the subjects, to get the points to go onto college. (PT09)

On a similar note, the benefits of fostering a reductionist approach to teaching were outlined by many teachers, as the predictability of examination questions afforded teachers the opportunity to "taper" (PT02) syllabus content down. This theme also permeated practical coursework assessments:

I had two students last year, two A's in woodwork, no joints in their pieces. Yet they spent first year and second year hacking through, with me over their shoulder hounding it into them, they learned from that but yet it wasn't examined. (PT03)

In contrast to this, the graphics-based subjects did not afford this opportunity. PT11 depicts the necessity of students to be able to understand and apply graphical principles to unique problems:

...thinking for yourself would be the big [focus] ... one of the things I would be trying to push with them because they are good kids and like as I say you can cover 101 situations but 102 will come up on the paper and to be able to think too, 'right we never did this but hang on, I know how to do that and I know how to do that and maybe this might work for this' and to have the confidence to attack it rather than say 'we never did that'... (PT11)

This theme may provide insight on the prevalence of holistic development activities undertaken by teachers in the 24-30 professional life phase (Fig. 2) or insights into the nature of activity within graphics based subjects.

\section{Professional views on capability}

An unexpected theme which emerged from the analysis was teachers questioning the nature of teaching and learning in the discipline. This theme comprised of two interrelated key factors. Firstly, participants highlighted the variance between what was of value (in their opinion) and what was valued at a systemic level:

Doing a day exam ... because it has no relevance whatsoever at the moment. I think it's just totally obsolete and the sooner the syllabus changes the better. (PT08)

... the unfortunate thing with the construction course is that, and this is reflected in the papers, that you can virtually predict you know, five, six, seven of the questions 
that come up year on year. A lot of the topics that come up are ones that would have been done - traditionally years ago are now redundant and basically don't need to be taught. So, you would find then that you would have a little bit more time if you pick your topics carefully. (PT02)

Secondly, a common theme emerged where teachers questioned the nature of the activity they engaged with. This appeared to be driven by participants questioning the validity of what they spend their time on, in that they engaged with tasks and activities that align with an agenda that they do not perceive to be of the upmost importance. In particular, the summative written or 'theory' examinations appeared to take time away from what teachers' perceive to be of more importance:

March up until the end of the year, unfortunately because of the Junior Certificate the way it is, they have to sit a theory exam, I'm covering constant theory with them. (PT01)

Traditionally, in fifth year, it's an awful lot of theory. We try to cover the whole course in fifth year apart from two questions - apart from question 8 and question 7 and we do them in sixth year... (PT15)

... in my head, right I have so much to get done, we do this today, we do this tomorrow. I know it's not ideal but you are facing the exam at the end, and you have to have the topics covered... (PT10)

This trend continued in relation to meeting the requirements of the 'practical day exam'. In this instance, PT09 rationalises their decision to focus exclusively on a development of practical skills, and move away from project-based learning in higher-secondary education:

...you can't afford to spend the time doing them. Its joints, joints, joints! It sounds very traditional but it's what gets them the results in the exam, it really is... (PT09)

\section{Implications and emerging research agenda}

Kimbell (1994) discussed the procedural progression of learning activities in design and technology education, stating that the framework of constraints in activities becomes increasingly looser as students progress, as the beginning years of study are important in developing the foundational skills and knowledge bases required to engage with the discipline (Kimbell and Stables 2007). As such, the findings of this study indicate that the first year of schooling is critical in the development of technical competencies. Similar to the progression depicted by Kimbell and Stables, the findings presented herein suggest that student autonomy through independent design thinking does increase as students progress through their schooling. However, the extent of this increase in autonomy is relatively minor, as a very focused series of tasks and activities are used to develop technical competencies throughout each year of schooling. The negative implication of this is limited engagement with authentic design problems, despite the philosophical shift in policy. When engagement with design is mandated through the assessment of a design portfolio, teachers adopt a methodological and formulaic approach to design in some cases, utilising the assessment rubric as a guide to their instructive practices. Atkinson (1994) depicted the tendency for teachers to view designing as a process of jumping through hoops in a predetermined order, and this appears true from the perspective of teachers that engaged with this study. 
It is arguable that such activities, bereft of opportunities to problem-solve and make value-laden decisions, are not aligned with the concept of technological capability. Capability suggests the ability to achieve something new, based on the acquisition of certain capacities relevant to a discipline. Critically, it provides one with the effective opportunities to progress (Sen 1987). In the case of technology education it may be the capacity to critique (Kimbell and Stables 2007), speculate (Dakers 2016), or make informed decisions (Kimbell 2017) that lies at the heart of technological capability. But without the effective opportunities to nurture and enhance such capacities through appropriate tasks and activities, capability is not the focus, or the outcome. Perhaps a more appropriate term for the outcome of current practices would be technical competence as competence is indicative of the capacity to do something; a defined something. Many of the learning activities discussed in this study align with a competence based output, in that they effectively prepare students for the examination system.

The findings highlight the pressures of meeting the requirements of summative assessments as having a significant influence on classroom practice. This theme was evident in teachers' narrow engagement with designing, the conscious decisions to truncate syllabi in the circumnavigation of prescribed content, and the general emphasis placed on content and level of attainment rather than learning outcomes. The influences that examinations have on practice in Irish education have been well documented (c.f. Hennessy et al. 2011; MacAogáin 2005). Unsurprisingly, one of the most often cited points of causation is the high stakes nature of second-level education assessment, as results govern matriculation into third-level education (Hyland 2011). Similar findings are reported here, through participants citing their schools as "high achieving" and detailing the resultant cultural expectations placed upon them, ultimately abetting a 'teaching towards the exam' epistemology. Despite the dominance of this paradigm, exceptions were observed, and may be more fruitful in exploring how to affect practice.

Firstly, it was notable that the engagement of higher cognitive functions, such as complex problem-solving and application of principles in innovative ways, was perceived as being of value in the graphics-based subjects. This resulted in classroom practice focusing on the development of problem-solving capacities and approaches to novel questions. Similar to other findings in this study, the nature of the examination was cited as the core influence on this. Critically however, the unpredictable nature of the examination negated a rote-learning approach as inefficient in this context, suggesting the potential for a rigorous constructive (re)alignment (Biggs 1996; Biggs and Tang 2011), where assessment methods enhance practice through their alignment with policy and intended outcomes.

Secondly, it was clear that there were stark differences in what teachers perceived to be of value in the discipline and what they engaged with in the classroom. Evidence in their questioning of elements of the syllabus and assessment systems highlights two interrelated issues. Teachers utilising tasks and activities which misalign with what they perceive to be of importance suggests a contention in understandings of capability. This potential misalignment between what is valued in the discipline as evidenced through teachers grappling with what is of value, highlights the need to understand conceptions of capability. There are multiple perspectives to this. Most notably; Is there a consensual understanding of capability among teachers? Is there consensus between what teachers perceive capability to be and what the syllabus prescribes capability to be? Is there a unilateral implementation of tasks and activities to develop capability in Irish technology education? Or, is the view and associated pedagogies agreed by all stakeholders?

The major implication stemming from this ambiguity around capability is the resultant effect on the nature of teaching and learning, specifically how conceptions influence 
practices. Much of the evidence presented suggests that there are impediments to teachers enacting what they conceive to be important to the discipline. The high stakes nature of assessment among others emerged as a significant influence on practices for example. However, evidence emerged to suggest that teachers are not explicitly focused on assessment, and that teachers' goals for the subject may adapt depending on a multitude of variables. Understanding the complex nature of influencers may afford the opportunity to clarify the contentions around capability in design and technology education.

\section{Conclusion}

Spendlove (2012) describes the tension between teaching subject content and processes as the "perennial debate" (p. 43) in technology education. From the perspective of Irish technology education policy, a shift has occurred and syllabi now situate processes, by proxy of the concept of technological capability, as the focus of the discipline. The essence of the emerging research agenda is to develop an insight into the relationship between the enactment of practices and the articulation and definition of capability, in the context of design driven education. Careful consideration must be given to the context and situation of the complex relationship between intended and enacted curriculum so as to recognise the pressures of meeting the requirements of national assessments.

Critically, from the perspective of this research, teachers appear cognisant of the contentions between their epistemological perspective and what is determined as capability, through their questioning of syllabus and assessment systems. Interpretation of the data would suggest a number of reasons for this, practicing teachers may have a refined understanding of capability through practice, but the pressures of meeting the requirements of the performative system subvert their pedagogical aspirations to enact developed conceptions. Alternatively, it is possible that there are misalignments between teachers' conceptions of what is important in the discipline, especially considering the shift from technical to design orientated learning outcomes. In either case, the evidence presented in this paper supports the framing of an evolving research agenda focused on better understanding enacted practice. This agenda is concerned with two critical issues; (1) what are the conceptions of capability in technology education, and (2) how these conceptions relate to perspectives on practice. Therefore, future research is required to unpack understandings of capability in the Irish context, and establish a benchmarked reference to international best practice. Once established, the manifestation of conceptions in enacted practices can be better understood.

Open Access This article is distributed under the terms of the Creative Commons Attribution 4.0 International License (http://creativecommons.org/licenses/by/4.0/), which permits unrestricted use, distribution, and reproduction in any medium, provided you give appropriate credit to the original author(s) and the source, provide a link to the Creative Commons license, and indicate if changes were made.

\section{References}

Anderson, L. W., \& Krathwohl, D. R. (2001). A taxonomy for learning, teaching, and assessing: A revision of Bloom's taxonomy of educational objectives. New York, NY: Longman.

Atkinson, S. E. (1994). Key factors which affect pupils' performance in technology project work. In J. S. Smith (Ed.), IDATER 1994 (pp. 30-37). Loughborough: Design and Technology, Loughborough University. 
Banks, F. (2000). Teaching design and technology. In G. Owen-Jackson (Ed.), Learning to teach design and technology in the secondary school (pp. 150-196). London: Routledge Falmer.

Banks, F., \& Barlex, D. (1999). "No one forgets a good teacher!": What do "good" technology teachers know? Journal of Design \& Technology Education, 4(3), 223-229.

Biggs, J. (1996). Enhancing teaching through constructive alignment. Higher Education, 32(3), 347-364.

Biggs, J., \& Tang, C. (2011). Teaching for quality learning at university: What the student does (4th ed.). Berkshire: McGraw-Hill Education.

Black, P., \& Harrison, M. (1985). In place of confusion: Technology and science in the school curriculum. Nuffield-Chelsea Curriculum Trust/National Centre for School Technology. Nottingham: Trent Polytechnic.

Bruce-Davis, M. N., Gubbins, E. J., Gilson, C. M., Villanueva, M., Foreman, J. L., \& Rubenstein, L. D. (2014). STEM high school administrators', teachers', and students' perceptions of curricular and instructional strategies and practices. Journal of Advanced Academics, 25(3), 272-306.

Cohen, L., Manion, L., \& Morrison, K. (2007). Research methods in education (6th ed.). London: Routledge.

Commission on the Points System. (1999). Commission on the points system: Final report and recommendations. Dublin: Stationary Office.

Crano, W. D., Brewer, M. B., \& Lac, A. (2015). Principles and methods of social research (3rd ed.). New York: Routledge.

Dakers, J. R. (2005a). Technology education as solo activity or socially constructed learning. International Journal of Technology and Design Education, 15(2), 73-89.

Dakers, J. R. (2005b). The hegemonic behaviorist cycle. International Journal of Technology and Design Education, 15(2), 111-126.

Dakers, J. R. (2016). Speculative multidimensional time-line thinking: A wobbly pedagogy to assist in the process of becoming technologically literate. In M. J. de Vries, A. Bekker-Holtland \& G. van Dijk (Eds.), 32nd pupils' attitude towards technology (PATT) conference (pp. 128-134). 23-26th August, Utrecht, Netherlands.

Dave, R. H. (1970). Psychomotor levels. In R. J. Armstrong (Ed.), Developing and writing behavioural objectives (pp. 33-34). Tucson: Educational Innovators Press.

Day, C., \& Gu, Q. (2007). Variations in the conditions for teachers' professional learning and development: Sustaining commitment and effectiveness over a career. Oxford Review of Education, 33(4), 423-443.

Dow, W. (2014). Implicit theories: Their impact on technology education. In J. R. Dakers (Ed.), Defining technological literacy: Towards an epistemological framework (2nd ed., pp. 149-164). New York, NY: Palgrave MacMillan.

Gagel, C. W. (2004). Technology profile: An assessment strategy for technological literacy. Journal of Technology Studies, 30(4), 38-45.

Gibson, K. (2008). Technology and technological knowledge: A challenge for school curricula. Teachers and Teaching: Theory and Practice, 14(1), 3-15.

Glaser, B. G., \& Strauss, A. L. (1967). The discovery of grounded theory: Strategies for qualitative research. Chicago: Aldine.

Gleeson, J. (2012). The professional knowledge base and practice of Irish post-primary teachers: What is the research evidence telling us? Irish Educational Studies, 31(1), 1-17.

Gleeson, J. (2014). We can't change the classroom until our outdated exam system is revised (p. 27). Dublin: Irish Independent.

Hennessy, J., Hinchion, C., \& Mannix Mcnamara, P. (2011). "The points, the points, the points": Exploring the impact of performance oriented education on the espoused values of Senior Cycle poetry teachers in Ireland. English Teaching: Practice and Critique, 10(1), 181-198.

Hyland, Á. (2011). Entry to higher education in Ireland in the 21st Century. Dublin: National Council for Curriculum and Assessment and the Higher Education Authority.

Kelly, V., Kimbell, R., Paterson, V., Sexton, J., \& Stables, K. (1987). Design and technology: A framework for assessment. London: HMSO.

Kimbell, R. (1994). Tasks in technology: An analysis of their purposes and effects. International Journal of Technology and Design Education, 4(3), 241-256.

Kimbell, R. (2011). Wrong... but right enough. Design and Technology Education: An International Journal, 16(2), 6-7.

Kimbell, R. (2017). Decisions by design. Design and Technology Education: An International Journal, 22(2), 5-7.

Kimbell, R., \& Stables, K. (2007). Researching design learning: Issues and findings from two decades of research and development. Dordrecht: Springer. 
Kimbell, R., Stables, K., \& Green, R. (1996). Understanding practice in design and technology. Buckingham: Open University Press.

Krathwohl, D. R., Bloom, B. S., \& Masia, B. B. (1964). Taxonomy of educational objectives, the classification of educational goals. Handbook II: Affective domain. New York, NY: David McKay Co., Inc.

MacAogáin, E. (2005). The points system and grading of the leaving certificate examination. The Irish Journal of Education/Iris Eireannach an Oideachais, 36, 3-24.

Mittell, I., \& Penny, A. (1997). Teacher perceptions of design and technology: A study of disjunction between policy and practice. International Journal of Technology and Design Education, 7(3), 279-293.

NCCA. (2004). Review of technology education in the junior cycle. Dublin: Department of Education and Science.

NCCA. (2007a). Leaving certificate design and communication graphics syllabus. Dublin: Department of Education and Science.

NCCA. (2007b). Leaving certificate technology syllabus. Dublin: Department of Education and Science.

OECD. (1991). Reviews of national policies for education: Ireland. Paris: OECD.

Owen-Jackson, G. (2015). Learning to teach design and technology in the secondary school: A companion to school experience (3rd ed.). Abingdon: Routledge.

Patton, M. Q. (2002). Qualitative evaluation and research methods (3rd ed.). Thousand Oaks, CA: Sage Publications Inc.

Reinsfield, E., \& Williams, P. J. (2017). New Zealand secondary technology teachers' perceptions: "Technological" or "technical" thinking? International Journal of Technology and Design Education. https://doi.org/10.1007/s10798-017-9418-z.

Sen, A. (1987). Commodities and capabilities. New Delhi: Oxford University Press.

Shiel, G., Perkins, R., \& Gilleece, L. (2009). OECD teaching and learning international study (TALIS): Summary report for Ireland. Dublin: Educational Research Centre.

Spendlove, D. (2012). Teaching technology. In P. J. Williams (Ed.), Technology Education for Teachers (pp. 35-54). Rotterdam: Sense Publishers.

Strauss, A. L., \& Corbin, J. M. (1998). Basics of qualitative research: Techniques and procedures for developing grounded theory. Newbury Park, CA: Sage Publications Inc. 